\title{
ANALISIS PENYUSUNAN MODEL PENDUGAAN VOLUME POHON 3 JENIS SHOREA DI TARAKAN, KALIMANTAN UTARA
}

Analysis of tree volume prediction models development for 3 Shorea species in Tarakan, North Kalimantan

\section{Farida Herry Susanty \& Abdurachman}

Balai Besar Penelitian dan Pengembangan Ekosistem Hutan Dipterokarpa, Jl. AW. Syahrani No. 68, Sempaja, Samarinda, Kalimantan Timur, Indonesia.

Telp. 0541206364, Fax. 0541742298,

Email: fhsusanty@gmail.com, abdurachmansh1@yahoo.co.id

Diterima : 16 Mei 2016, direvisi : 22 Juni 2016, disetujui : 31 Juli 2016

\begin{abstract}
ABSTRAK
Penelitian ini bertujuan untuk membangun model dugaan volume pohon Dipterocarpaceae yaitu jenis Shorea parvifolia, $S$. dasyphylla dan S. leprosula. Pengumpulan data dilakukan dengan menggunakan pendekatan pengukuran pohon dengan Spiegel Relaskop. Analisis kurva tinggi menunjukkan hubungan yang signifikan antara diameter setinggi dada dan tinggi bebas cabang, sehingga selanjutnya penyusunan model pendugaan volume hanya berdasarkan variabel diameter saja (Tariff). Penyusunan model pendugaan volume menggunakan analisis stepwise regression. Pemilihan model terbaik pada tahap pembangunan model berdasarkan nilai koefisien determinasi $\left(\mathrm{R}^{2}\right)$, standar error (SE) dan

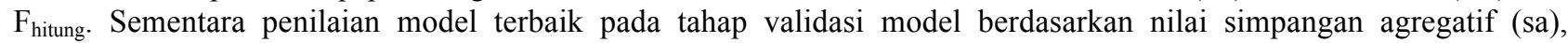
simpangan rataan (sr) dan Root Mean Square Error (RMSE). Model Berkhout diterima sebagai model terbaik untuk ketiga jenis yang diteliti, yaitu $S$. parvifolia: $\mathrm{V}=0,00007979 . \mathrm{D}^{2,67646}$, S. dasyphylla: $\mathrm{V}=0,00005024 . \mathrm{D}^{2,80036}$ dan $S$. leprosula: $\mathrm{V}=0,000082137 . \mathrm{D}^{2,67286}$ untuk wilayah hutan alam Tarakan. Model volume gabungan untuk 3 jenis tersebut mempunyai bentuk model Gehrhardt-Kopezky yaitu $\mathrm{V}=-0,43029+0,001392 . \mathrm{D}^{2}$.
\end{abstract}

Kata kunci : Shorea parvifolia, S.dasyphylla, S.leprosula, tabel volume

\section{ABSTRACT}

The aim of this study is to develop tree volume prediction models of three Dipterocarpaceae species, namely Shorea parvifolia, S. dasyphylla and S. leprosula. Data collection in this study was conducted by measuring diameter and height of trees using Spiegel Relaskop. Height curve analysis showed a significant relationship between diameter at breast height and bole height, thus the development of tree volume prediction models only used diameter as a single predictor variable (Tariff). Tree volume prediction models were developed using stepwise regression analysis. Selection of the best models was based on the values of the coefficient of determination $\left(R^{2}\right)$, standard error $(S E)$ and $F_{\text {test }}$. While model validation for best model assessment was based on the values of aggregate deviation (sa), average deviation (sr) and Root Mean Square Error (RMSE). Berkhout models were accepted as the best model for three Dipterocarp species in Tarakan natural forest, namely S. parvifolia: $V=0,00007979 . D^{2,67646}$, S. dasyphylla: $V=0,00005024 . D^{2,80036}$ and $\mathrm{S}$. leprosula: $V=0,000082137 . D^{2,6728}$. The combined volume model for these 3 species has Gehrhardt-Kopezky model, $V=$ $-0,43029+0,001392 \cdot D^{2}$.

Keywords : Shorea parvifolia, S.dasyphylla, S.leprosula, volume table

\section{PENDAHULUAN}

Salah satu alat bantu yang esensial dalam pelaksanaan inventarisasi hutan dan pendugaan pertumbuhan dan hasil adalah model-model atau tabel-tabel penduga volume pohon (Utomo dan Rachman, 2002). Kesalahan terhadap penaksiran potensi massa tegakan tersebut akan mengakibatkan kesalahan penaksiran produksi yang selanjutnya berakibat pada kesalahan dalam menganalisis ekonomi (untung-rugi) dalam pengusahaan hutan (Siswanto dan Imanuddin, 2008). Pentingnya perangkat manajemen kuantitatif berdasarkan pada data dan informasi yang valid akan mendukung pengelolaan hutan lebih akurat (Prodan, 1968; Phillips, 1998).

Pengetahuan mengenai kuantitas dan kualitas kayu sangat berguna bagi para pengelola hutan. Pengukuran kayu merupakan penyedia informasi dan sebagai bagian dari rencana pengelolaan hutan. Oderwald and Johnson (2004) dari Virginia Polytechnic Institute and State University, menyatakan bahwa kayu dapat dijual dalam bentuk berdiri (pohon) atau produk tebangan (kayu gergajian, 
veneer atau kayu pulp). Jika pohon dijual dalam produk tebangan umumnya berdasarkan pengukuran volume, sedangkan untuk pohon berdiri berdasarkan pengukuran estimasi volume tegakan atau individu pohon. Usahausaha kearah penyempurnaan metode inventarisasi potensi hutan tidak terlepas dari usaha-usaha penyusunan tabel isi tiap pohon yang cukup seksama sehingga dapat meningkatkan keakuratan hasil inventarisasi, massa tegakan bagi jenis kayu perdagangan yang bersangkutan, agar penentuan dan pengaturan penebangan (annual allowable cut) dapat dilaksanakan lebih obyektif sehingga produksi dapat lebih terjamin.

Husch et al. (2003) menyatakan bahwa berdasarkan kegunaannya, tabel volume dibedakan menjadi: tabel volume lokal yang berfungsi untuk menduga volume pohon atau tegakan yang bersifat lokal spesifik, dan tabel volume standar yang digunakan lebih umum untuk seluruh areal. Istilah ini menurut Loetsch et al. (1973) adalah dapat menyesatkan karena seringkali tabel volume standar dibentuk hanya untuk daerah tertentu, yang berarti pula penggunaan tabel di luar daerah tersebut dapat menimbulkan bias. Penggunaan tabel volume pohon (kayu) dapat dikembangkan dalam pemanfaatannya sesuai dengan kebutuhan dan tuntutan secara lokal (Heigliman dan Bratkovich, 2002; Oderwald dan Johnson, 2004).

Pemerintah mewajibkan setiap pengelola hutan menyusun tabel/tariff volume pohon untuk jenis atau kelompok jenis yang ada di areal pengusahaannya. Sejalan dengan hal tersebut, ketersediaan tabel/tariff volume pohon juga telah dicantumkan sebagai salah satu kriteria dan indikator sertifikasi ekolabeling. Dalam SK Menteri Kehutanan No. 4795 dan N0. 4796 tahun 2002 tentang Kriteria dan Indikator Pengelolaan Hutan Alam Produksi Lestari (PHAPL) dalam kriteria produksi pada unit pengelolaan mempertimbangkan komitmen pengelola hutan dalam penyediaan perangkat-perangkat yang menunjang dalam perencanaan pengelolaan hutan, salah satunya adalah tersedianya tabel volume pohon (Anonim, 1998). Dalam kewajiban para pemegang Ijin Usaha Pemanfaatan Hasil Hutan Kayu (IUPHHK) untuk melaksanakan Inventarisasi
Hutan Menyeluruh Berkala (IHMB) dalam Peraturan Pemerintah Nomor 6 tahun 2007 tentang tata hutan dan penyusunan rencana pengelolaan hutan serta pemanfaatan hutan, salah satunya ditentukan oleh ketersediaan tabel volume pohon. Sistem pengaturan hasil berdasarkan data dan informasi yang bersifat asumsi akan cenderung memberikan pola pemanfaatan hutan alam yang kurang rasional dan optimal. Perlunya penyediaan perangkat manajemen kuantitatif dalam rangka menetapkan preskripsi kunci pengaturan hasil sampai dengan tingkat tapak. Salah satu kajian yang perlu untuk dilakukan adalah penyusunan pendugaan volume pohon berbasis jenis atau kelompok jenis untuk suatu kondisi hutan tertentu.

Tujuan penelitian ini adalah untuk menyusun dan menentukan model pendugaan volume pohon terbaik sebagai bahan penyusunan tabel volume lokal (tariff) jenis Dipterocarpaceae. Sehingga dapat meningkatkan keakuratan dalam penaksiran massa tegakan (potensi hutan) pada hutan alam produksi di Kalimantan. Dengan tersusunnya perangkat penduga volume pohon berupa tabel volume berdasarkan jenis dan kondisi tapak yang spesifik akan memberikan estimasi volume pohon dan hutan yang lebih valid.

\section{METODOLOGI PENELITIAN}

\section{A. Lokasi Penelitian}

Kegiatan penelitian dilaksanakan di kawasan hutan alam produksi dalam wilayah konsesi pengusahaan hutan alam IUPHHK-HA PT. Intracawood Manufacturing, Tarakan Propinsi Kalimantan Utara. Berdasarkan batas geografi, areal terletak antara $2^{\circ} 48^{\prime} 27^{\prime \prime}-3^{\circ}$ 37' 30" Lintang Utara (LU) dan $116^{\circ} 30^{\prime} 00^{\prime}$ " $117^{\circ} 11$ ' 44" Bujur Timur (BT).

Berdasarkan buku laporan revisi Rencana Kerja Usaha Pemanfaatan Hasil Hutan Kayu dalam Hutan Alam pada Hutan Produksi Berbasis Inventarisasi Hutan Menyeluruh Berkala (IHMB) PT. Intracawood Manufacturing Periode Tahun 2008- 2017, menyatakan bahwa secara umum kondisi hutan didominasi oleh hutan hujan tropika basah (tropical rain forest) yang terbagi berdasarkan zona ketinggian tempat terdapat tipe hutan hutan dipterokarpa dataran rendah dan hutan dipterokarpa dataran tinggi. 
Berdasarkan data iklim dari dua stasiun terdekat yaitu stasiun pengamat iklim Tarakan, berdasarkan klasifikasi iklim Schmidt dan Fergusson (1952) termasuk dalam tipe A.

\section{B. Prosedur Penelitian}

Pengukuran pohon sampel menggunakan pendekatan pengukuran pohon berdiri menggunakan spigel relaskop (Loetsch et al., 1973). Pengumpulan data meliputi: jenis, diameter setinggi dada, diameter seksi, tinggi bebas cabang dan jarak pengukuran.

Pengolahan dan analisis data meliputi :

1. Distribusi sebaran pohon sampel berdasarkan representatif dalam penyusunan dan validasi model;

2. Analisis kurva tinggi untuk mengetahui hubungan antara diameter dan tinggi dilakukan dengan analisis regresi dengan 'scatter diagram technique' berdasarkan nilai koefisien korelasi (r) dan koefisien determinasi $\left(\mathrm{R}^{2}\right)$. Pengujian koefisien korelasi dengan uji $\mathrm{Z}_{\text {fisher }}$ (Walpole, 1993).

3. Penyusunan model pendugaan volume pohon, berdasarkan hasil penelitian sebelumnya (Lestarian, 2009; Ardelina, 2011; Riady, 2011; Permadi, 2014), menunjukkan bahwa beberapa persamaan pendugaan volume yang banyak dikembangkan dan dicobakan berdasarkan hasil analisis kurva tinggi dalam penelitian ini meliputi model-model berikut (Loetsch et al., 1973) :

Model tabel volume lokal :

$$
\begin{aligned}
& \mathrm{V}=\mathrm{b}_{0}+\mathrm{b}_{1} \cdot \mathrm{d}^{2} \quad \text { (Kopezky-Gehrhardt) } \\
& \mathrm{V}=\mathrm{b}_{0} \cdot \mathrm{d}^{\mathrm{b} 1} \quad \text { (Berkhout) } \\
& \mathrm{V}=\mathrm{b}_{0}+\mathrm{b}_{1} \cdot \mathrm{d}+\mathrm{b}_{2} \cdot \mathrm{d}^{2} \quad \text { (Hohenadl-Krenn) }
\end{aligned}
$$

Model tabel volume standar:

$$
\begin{array}{ll}
\mathrm{V} & =\mathrm{b}_{0}+\mathrm{b}_{1} \cdot \mathrm{d}^{2}+\mathrm{b}_{2} \cdot \mathrm{d}^{2} \mathrm{~h}+\mathrm{b}_{3} \mathrm{~h} \quad \text { (Stoate) } \\
\mathrm{V}=\mathrm{b}_{0} \cdot\left(\mathrm{d}^{2} \mathrm{~h}\right)^{\mathrm{b} 1} & \text { (Spurr) } \\
\mathrm{V}=\mathrm{b}_{0} \cdot \mathrm{d}^{\mathrm{b} 1} \cdot \mathrm{h}^{\mathrm{b} 2} \quad \text { (Schumacher-Hall) }
\end{array}
$$

Pemilihan persamaan/model yang paling sesuai dilakukan dengan diagram scatter technique berdasarkan nilai koefisien korelasi (r) dan koefisien determinasi $\left(\mathrm{R}^{2}\right)$ tertinggi serta nilai standar eror (SE) terkecil (Steel dan Torrie, 1995). Koefisien determinasi dihitung berdasarkan rumus sebagai berikut :

$$
\mathrm{R}^{2}=\mathrm{JKR} / \mathrm{JKT}
$$

dimana :

$\mathrm{R}^{2}=$ Koefisien Determinasi

$\mathrm{JKR}=$ Jumlah Kuadrat Rataan

$\mathrm{JKT}=$ Jumlah Kuadrat Tengah

Nilai koefisien korelasi

(r) dihitung berdasarkan rumus berikut:

$$
r=\sqrt{R^{2}}
$$

Nilai koefisien determinasi berkisar antara 0 sampai 1, sedangkan nilai kofisien korelasi berkisar dari -1 sampai +1 . Model regresi dilakukan pengujian dengan menggunakan analisis keragaman (analysis of variance) untuk melihat signifikansi atau adanya ketergantungan antar peubah penyusun regresi.

4. Validasi (pengabsahan) model menggunakan nilai-nilai persentase simpangan baku residual (Alders, 1981 yang dikutip oleh Pambudhi, 1995). Semakin kecil nilai persentase simpangan baku residual akan menunjukan semakin baik persamaan volume yang diperoleh. Validasi model didasarkan pada besarnya simpangan agregatif (Sa), simpangan rataan (Sr) dan Root Mean Square Error (RMSE). Perhitungan $\mathrm{Sa}, \mathrm{Sr}$ dan RMSE didasarkan pada rumus Bruce (dalam Husch, 1963) dengan modifikasi (Bustomi et al., 1998) adalah sebagai berikut :

$$
\begin{aligned}
& \mathrm{S}_{\mathrm{a}}=\left\{\sum\left(\mathrm{V}_{\mathrm{d}}-\mathrm{V}_{\mathrm{a}}\right) / \mathrm{V}_{\mathrm{d}}\right\} \\
& \mathrm{S}_{\mathrm{r}}=\left[\sum\left|\left(\mathrm{V}_{\mathrm{d}}-\mathrm{V}_{\mathrm{a}}\right) / \mathrm{V}_{\mathrm{d}}\right| \times 100 \%\right] / \mathrm{n} \\
& \mathrm{RMSE}=\left(\sqrt{\sum}\left[\mathrm{V}_{\mathrm{d}}-\mathrm{V}_{\mathrm{a}} / \mathrm{V}_{\mathrm{a}}\right]^{2} / \mathrm{n}\right) \times 100 \%
\end{aligned}
$$

dimana :

$\mathrm{V}_{\mathrm{d}}=$ volume dugaan (yang diperoleh dari model)

$\mathrm{V}_{\mathrm{a}}=$ volume aktual (yang diperoleh dari data)

$\mathrm{n}$ = banyaknya sample.

Spurr (1952) dan Husch (1963) berpendapat bahwa model pendugaan volume pohon yang baik adalah persamaan yang mempunyai nilai SA kurang dari $1 \%$ dan SR kurang dari $10 \%$.

\section{HASIL DAN PEMBAHASAN}

\section{A. Sebaran Data Pohon Sampel}

Pemilihan pohon sampel untuk penyusunan model dan validasi model dilakukan secara purposive berdasarkan keterwakilan kelas diameter pohon (Susanty dan Siran, 2005). Tahap awal pembentukan 
tabel volume meliputi pemilihan pohonpohon contoh untuk penyusunan persamaan regresi hubungan volume dengan diameter menggunakan kira-kira 2/3-3/4 dari jumlah pohon contoh, sedangkan pengujian persamaan regresi yang diperoleh untuk menentukan akurasinya menggunakan kirakira 1/4 - 1/3 dari jumlah pohon contoh. Terpilihnya pohon sampel di lapangan tergantung pada sebaran jenis tersebut di lapangan. Variasi jumlah pohon sampel yang diperoleh akan mempengaruhi tingkat aplikasi dari hasil penyusunan model pendugaan volume. Dengan pertimbangan bentuk umum kondisi hutan alam yang mempunyai sebaran diameter tegakan berbentuk "J-terbalik", maka penentuan jumlah pohon model diarahkan seiring kenaikan kelas diameter (Bustomi et al., 1998). Penentuan jumlah pohon sampel untuk penyusunan dan validasi model secara purposif disajikan pada Tabel 1 berikut.

Tabel 1. Proporsi jumlah pohon sampel (n) untuk penyusunan dan validasi model

Table 1. Proportion numbers of sampling trees ( $n$ ) for development and validation model

\begin{tabular}{|c|c|c|c|c|c|c|c|c|}
\hline \multirow{2}{*}{$\begin{array}{c}\text { Kelas } \\
\text { Diameter } \\
(\mathrm{cm})\end{array}$} & \multicolumn{2}{|c|}{ S. parvifolia } & \multicolumn{2}{|c|}{ S. dasyphylla } & \multicolumn{2}{|c|}{ S. leprosula } & \multicolumn{2}{|c|}{ Jumlah } \\
\hline & n model & n validasi & n model & n validasi & n model & n validasi & n model & n validasi \\
\hline 10 & 8 & 2 & 2 & 1 & 1 & 1 & 11 & 4 \\
\hline 20 & 6 & 2 & 10 & 2 & 6 & 1 & 22 & 5 \\
\hline 30 & 9 & 2 & 11 & 3 & 8 & 2 & 27 & 7 \\
\hline 40 & 6 & 2 & 9 & 2 & 8 & 3 & 23 & 7 \\
\hline 50 & 2 & 1 & 5 & 2 & 3 & 1 & 10 & 4 \\
\hline 60 & 2 & 1 & 1 & & 1 & 1 & 4 & 2 \\
\hline 70 & & & & & & & 0 & 0 \\
\hline 80 & 1 & 1 & & & & & 1 & 1 \\
\hline 90 & & & 1 & & & & 1 & 0 \\
\hline$>100$ & 1 & & & & & & 1 & 0 \\
\hline Jumlah & 35 & 11 & 39 & 10 & 27 & 9 & 101 & 30 \\
\hline
\end{tabular}

Pemilihan pohon sampel baik untuk tahap penyusunan model dan validasi model dilakukan secara purposive (acak dalam kelas) berdasarkan keterwakilan kelas diameter pohon. Teknik penentuan jumlah sampel secara purposive dengan dasar pertimbangan keterwakilan pohon sampel baik untuk tahap penyusunan maupun validasi model (Lestarian, 2009; Fatah, 2009; Riady, 2011; Andhika, 2012; Ulfah, 2012; Permadi, 2014). Penetapan pohon sampel untuk setiap jenis Shorea di hutan alam sangat tergantung pada hasil pengumpulan pohon-pohon sampel dilapangan. Meninjau pola struktur pada hutan alam yang berbentuk kurva $\mathrm{J}$ terbalik, sehingga pohon sampel dengan diameter yang lebih kecil akan lebih banyak diperoleh dibandingkan untuk pohon berdiameter yang besar.

\section{B. Analisis Kurva Tinggi}

Rekapitulasi analisis kurva tinggi yang menunjukkan hubungan variabel diameter terhadap variabel tinggi bebas cabang pohon disajikan pada Tabel 2 berikut.

Tabel 2. Hasil analisis persamaan kurva tinggi berdasarkan nilai koefisien korelasi (r), koefisien determinasi $\left(\mathrm{R}^{2}\right)$ dan $\mathrm{Z}_{\text {hitung }}$

Table 2. Analysis result of height curve equations based on correlation coeficient value (r), determination coeficient value $\left(R^{2}\right)$ and $Z_{\text {test }}$

\begin{tabular}{lccccl}
\hline \multicolumn{1}{c}{ Jenis } & \multicolumn{1}{c}{$\mathbf{r}$} & $\mathbf{R}^{2}$ & $\mathbf{Z}_{\text {hitung }}$ & $\begin{array}{r}\mathbf{Z}_{\text {tabel }} \\
(\mathbf{0 . 0 5})\end{array}$ & \multicolumn{1}{c}{ Persamaan regresi } \\
\hline S. parvifolia & 0,803 & 0,645 & 12,80 & 4,057 & $\mathrm{~h}=-0,002 \mathrm{~d}^{2}+0,537 \mathrm{~d}+2,383$ \\
\hline S. dasyphylla & 0,718 & 0,515 & 5,32 & 4,038 & $\mathrm{~h}=-0,003 \mathrm{~d}^{2}+0,66 \mathrm{~d}-1,112$ \\
\hline S. leprosula & 0,723 & 0,523 & 4,14 & 4,149 & $\mathrm{~h}=1,065 \mathrm{~d}^{0.765}$ \\
\hline Gabungan & 0,748 & 0,559 & 7,61 & 3,914 & $\mathrm{~h}=-0,003 \mathrm{~d}^{2}+0,575 \mathrm{~d}+1,040$ \\
\hline
\end{tabular}

Keterangan: $\mathrm{h}=$ tinggi bebas cabang; $\mathrm{d}=$ diameter setinggi dada 
Batas ketelitian yang masih diperbolehkan dalam penyusunan tabel volume adalah nilai koefisien korelasi $>0,70$ atau koefisien determinasi minimal 50\% (Suharlan dan Sudiyono, 1977). Berdasarkan kriteria tersebut keempat bentuk persamaan menunjukkan adanya hubungan yang cukup erat antara variabel diameter setinggi dada dan tinggi bebas cabang. Hasil yang sama ditunjukkan dari hasil uji $Z$ fisher menunjukkan nilai $Z_{\text {hitung }}>Z_{\text {tabel(0.05) }}$ yang mengindikasikan adanya hubungan yang cukup erat antara kedua variabel tersebut (Walpole, 1993). Berdasarkan hasil tersebut, selanjutnya penyusunan model pendugaan volume dapat disusun menggunakan satu variabel diameter saja.

\section{Penyusunan Model Pendugaan Volume Pohon}

Berdasarkan hasil analisis kurva tinggi, maka penyusunan model pendugaan volume (Loetsch et al., 1973) meliputi bentuk persamaan dengan menggunakan variabel diameter saja.
Bentuk diagram pencar hubungan antara diameter setinggi dada $(\mathrm{cm})$ dan volume bebas cabang $\left(\mathrm{m}^{3}\right)$ yang terbentuk untuk jenis S. parvifolia, $S$. dasyphylla, S. leprosula dan gabungan (3 jenis) secara berturut-turut disajikan pada Gambar 1-3. Sedangkan hasil analisis model atau persamaan regresi pendugaan volume untuk jenis $S$. parvifolia, $S$. dasyphylla, $S$. leprosula dan gabungan (3 jenis) berturut-turut disajikan pada Tabel 3-5. Sedangkan untuk analisis model gabungan ketiga jenis disajikan pada Gambar 4 dan Tabel 6.

Dasar penilaian model atau persamaan terpilih adalah nilai koefisien korelasi (r) dan koefisien determinasi $\left(\mathrm{R}^{2}\right)$ tertinggi serta nilai standar error (SE) terkecil (Steel dan Torrie, 1995). Prodan (1965) menyebutkan bahwa suatu persamaan regresi dengan satu peubah bebas dapat dikatakan teliti bila kesalah bakunya tidak lebih dari $25 \%$, sedangkan dengan dua peubah bebas kesalahan bakunya tidak lebih dari $20 \%$.

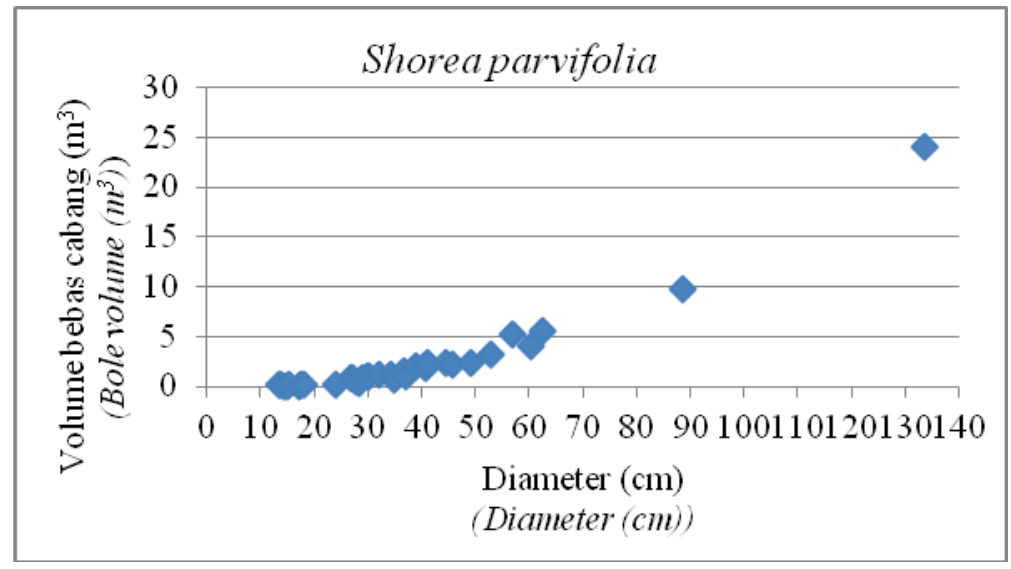

Gambar 1. Diagram pencar hubungan antara diameter setinggi dada $(\mathrm{cm})$ dan volume bebas cabang $\left(\mathrm{m}^{3}\right)$ untuk S. parvifolia

Figure 1. Scatter diagram of correlation between diameter breast height (cm) and bole volume $\left(\mathrm{m}^{3}\right)$ for $S$. parvifolia

Tabel 3. Hasil analisis persamaan model volume jenis $S$. parvifolia berdasarkan nilai koefisien determinasi $\left(\mathrm{R}^{2}\right)$, standar error (SE) dan $\mathrm{F}_{\text {hitung }}$

Table 3. Analysis result of volume regression equations of $S$. parvifolia based on determination coeficient value $\left(R^{2}\right)$, standar error $(S E)$ and $F_{\text {test }}$

\begin{tabular}{lcccccc}
\hline No. & Persamaan regresi & $\mathbf{R}^{\mathbf{2}(\%)}$ & $\mathbf{S E}$ & $\mathbf{F h i t}$ & $\mathbf{F}_{\text {tabel(0.05) }}$ & $\mathbf{F}_{\text {tabel(0.01) }}$ \\
\hline 1. & $\mathrm{~V}=-0,3381+0,001355 . \mathrm{d}^{2}$ & 99,29 & 0,3642 & $4.641,5$ & 4,13925 & 7,4708 \\
\hline 2. & $\mathrm{V}=0,00007979 . \mathrm{d}^{2,67646}$ & 95,18 & 0,1421 & 651,55 & & \\
\hline 3. & $\mathrm{~V}=0,001 \mathrm{~d}^{2}-0,007 \mathrm{~d}-0,156$ & 99,31 & 0,3650 & $2.309,95$ & & \\
\hline
\end{tabular}

Keterangan: $\mathrm{V}=$ volume bebas cabang $\left(\mathrm{m}^{3}\right) ; \mathrm{d}=$ diameter setinggi dada $(\mathrm{cm})$ 


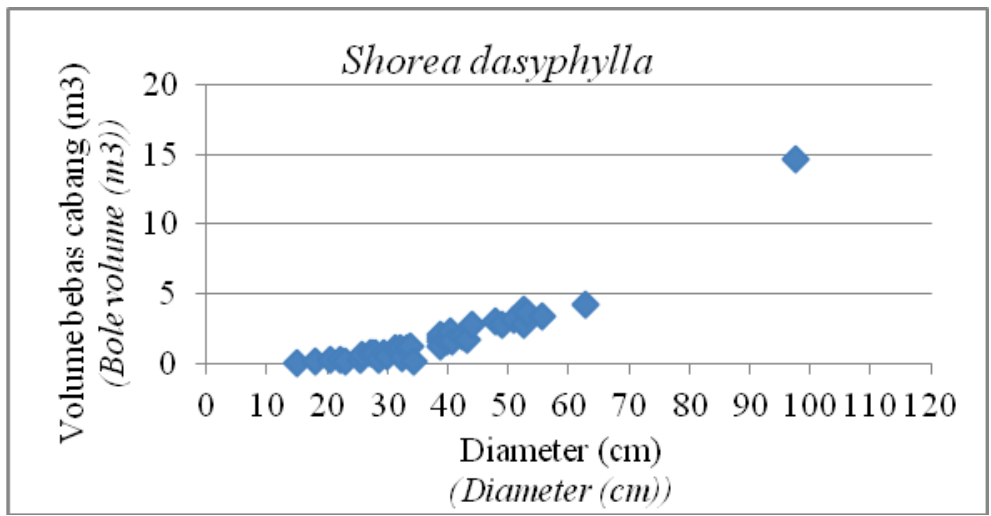

Gambar 2. Diagram pencar hubungan antara diameter setinggi dada $(\mathrm{cm})$ dan volume bebas cabang $\left(\mathrm{m}^{3}\right)$ untuk S. dasyphylla

Figure 2. Scatter diagram of correlation between diameter breast height $(\mathrm{cm})$ and bole volume $\left(\mathrm{m}^{3}\right)$ for $S$. dasyphylla

Tabel 4. Hasil analisis persamaan model volume jenis $S$. dasyphylla berdasarkan nilai koefisien determinasi $\left(\mathrm{R}^{2}\right)$, standar error (SE) dan $\mathrm{F}_{\text {hitung }}$

Table 4. Analysis result of volume regression equations of $S$. dasyphylla based on determination coeficient value $\left(R^{2}\right)$, standar error (SE) and $F_{\text {test }}$

\begin{tabular}{lcccccc}
\hline No. & Persamaan regresi & $\mathbf{R}^{\mathbf{2}} \mathbf{( \% )}$ & $\mathbf{S E}$ & Fhit & $\mathbf{F}_{\text {tabel(0.05) }}$ & $\mathbf{F}_{\text {tabel(0.01) }}$ \\
\hline 1. & $\mathrm{~V}=-0,6369+0,001517 . \mathrm{d}^{2}$ & 97,06 & 0,4156 & $1.222,93$ & 4,1055 & 7,3734 \\
\hline 2. & $\mathrm{V}=0,00005024 . \mathrm{d}^{2,80036}$ & 85,94 & 0,1814 & 226,24 & & \\
\hline 3. & $\mathrm{V}=0,001 \mathrm{~d}^{2}-0,045 \mathrm{~d}+0,389$ & 97,69 & 0,3740 & 760,16 & & \\
\hline
\end{tabular}

Keterangan: $\mathrm{V}=$ volume bebas cabang $\left(\mathrm{m}^{3}\right) ; \mathrm{d}=$ diameter setinggi dada $(\mathrm{cm})$

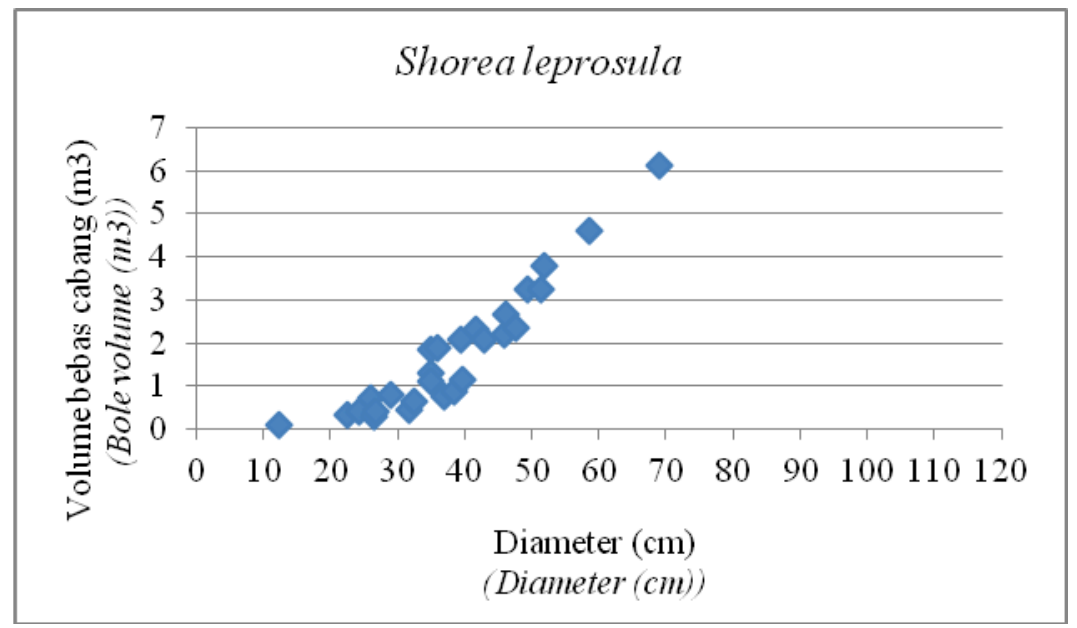

Gambar 3. Diagram pencar hubungan antara diameter setinggi dada $(\mathrm{cm})$ dan volume bebas cabang $\left(\mathrm{m}^{3}\right)$ untuk S. leprosula

Figure 3. Scatter diagram of correlation between diameter breast height $(\mathrm{cm})$ and bole volume $\left(\mathrm{m}^{3}\right)$ for $S$. leprosula

Tabel 5. Hasil analisis persamaan model volume jenis $S$. leprosula berdasarkan nilai koefisien determinasi $\left(\mathrm{R}^{2}\right)$, standar error (SE) dan $\mathrm{F}_{\text {hitung }}$

Table 5. Analysis result of volume regression equations of $S$. leprosula based on determination coeficient value $\left(R^{2}\right)$, standar error $(S E)$ and $F_{\text {test }}$

\begin{tabular}{lcccccc}
\hline No. & Persamaan regresi & $\mathbf{R}^{\mathbf{2}} \mathbf{( \% )}$ & $\mathbf{S E}$ & Fhit & $\mathbf{F}_{\text {tabel(0.05) }}$ & $\mathbf{F}_{\text {tabel(0.01) }}$ \\
\hline 1. & $\mathrm{~V}=-0,50766+0,001423 . \mathrm{d}^{2}$ & 93,68 & 0,3768 & 370,67 & 4,2417 & 7,7698 \\
\hline 2. & $\mathrm{V}=0,000082137 . \mathrm{d}^{2,67286}$ & 89,83 & 0,1389 & 221,01 & & \\
\hline 3. & $\mathrm{V}=0,001 \mathrm{~d}^{2}-0,025 \mathrm{~d}-0,026$ & 93,87 & 0,3786 & 183,91 & & \\
\hline
\end{tabular}

Keterangan : $\mathrm{V}=$ volume bebas cabang $\left(\mathrm{m}^{3}\right) ; \mathrm{d}=$ diameter setinggi dada $(\mathrm{cm})$ 


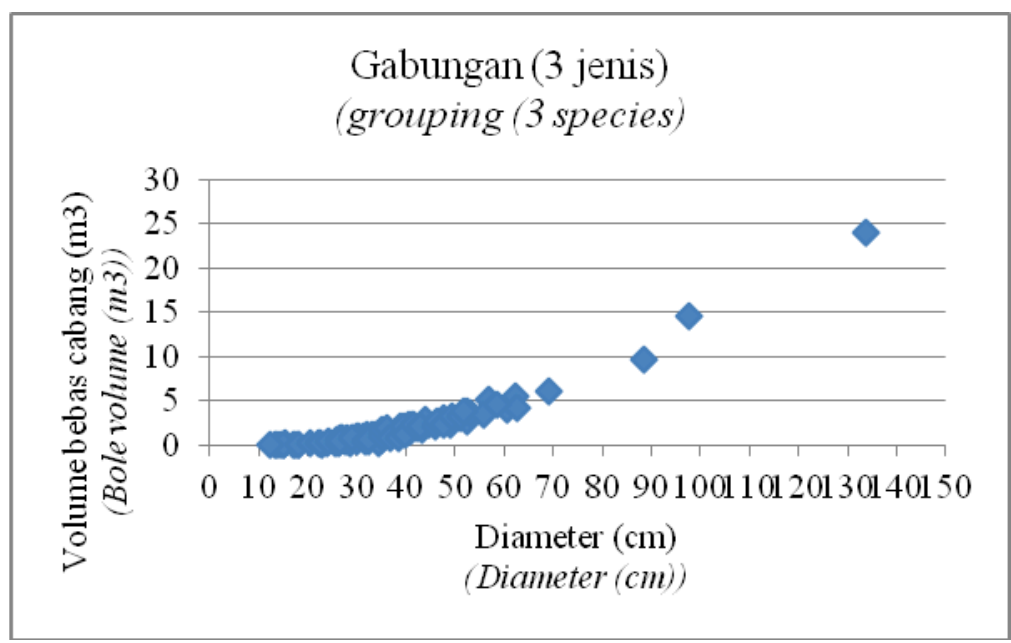

Gambar 4. Diagram pencar hubungan antara diameter setinggi dada $(\mathrm{cm})$ dan volume bebas cabang $\left(\mathrm{m}^{3}\right)$ untuk gabungan (3 jenis)

Figure 4. Scatter diagram of correlation between diameter breast height (cm) and bole volume $\left(\mathrm{m}^{3}\right)$ for grouping (3 species)

Tabel 6. Hasil analisis persamaan model volume gabungan (3 jenis) berdasarkan nilai koefisien determinasi $\left(\mathrm{R}^{2}\right)$, standar error (SE) dan $\mathrm{F}_{\text {hitung }}$

Table 6. Analysis result of volume regression equations for grouping (3 species) based on determination coeficient value $\left(R^{2}\right)$, standar error (SE) and $F_{\text {test }}$

\begin{tabular}{|c|c|c|c|c|c|c|}
\hline No. & Persamaan regresi & $\mathbf{R}^{2}(\%)$ & SE & Fhit & $F_{\text {tabel(0.05) }}$ & $F_{\text {tabel(0.01) }}$ \\
\hline 1. & $\mathrm{~V}=-0,43029+0,001392 \cdot \mathrm{d}^{2}$ & 98,19 & 0,4055 & $5.366,81$ & 3,9371 & 6,8980 \\
\hline 2. & $\mathrm{~V}=0,000070611 . \mathrm{d}^{2,71000}$ & 91,36 & 0,1551 & $1.046,47$ & & \\
\hline 3. & $\mathrm{~V}=0,001 \mathrm{~d}^{2}-0,006 \mathrm{~d}-0,278$ & 98,20 & 0,4057 & $2.680,50$ & & \\
\hline
\end{tabular}

Tabel 7. Penentuan peringkat pada tahap penyusunan model

Table 7. Scoring on model development stage

\begin{tabular}{llllll}
\hline \multicolumn{1}{c}{ Persamaan } & $\mathbf{R}^{2}$ & SE & $\mathbf{F}_{\text {hit }}$ & & Peringkat \\
\hline S. parvifolia & & & & 4 & 1 \\
\hline Kopezky-Gehrhardt & 1 & 2 & 1 & 7 & 2 \\
\hline Berkhout & 3 & 1 & 3 & 7 & 2 \\
\hline Hohenadl-Krenn & 2 & 3 & 2 & 6 & 2 \\
\hline S. dasyphylla & & & & & 3 \\
\hline Kopezky-Gehrhardt & 2 & 3 & 1 & 5 & 1 \\
\hline Berkhout & 3 & 1 & 3 & 4 & 1 \\
\hline Hohenadl-Krenn & 1 & 2 & 2 & 6 & 2 \\
\hline S. leprosula & & & & 6 & 2 \\
\hline Kopezky-Gehrhardt & 2 & 1 & 1 & 5 & 1 \\
\hline Berkhout & 3 & 1 & 2 & 7 & 3 \\
\hline Hohenadl-Krenn & 1 & 2 & 3 & 6 & 2 \\
\hline Gabungan & & & & & \\
\hline Kopezky-Gehrhardt & 2 & 2 & 1 & 3 & \\
\hline Berkhout & 3 & 1 & 2 & & \\
\hline Hohenadl-Krenn & 1 & 3 & &
\end{tabular}

Keterangan $: \mathrm{R}^{2}=$ koefisien determinasi; $\mathrm{SE}=$ standar error; $\mathrm{F}_{\text {hit }}=$ nilai $\mathrm{F}_{\text {hitung }}$

Berdasarkan hasil pemeringkatan pada tabel diatas menunjukkan bahwa model 
Kopezky-Gehrhardt paling banyak diterima, kecuali untuk jenis $S$. dasyphylla dengan model Hohenadl-Krenn. Pemilihan model terkait pula dengan aspek tingkat kepraktisan aplikasi model tersebut. Penggunaan fungsifungsi logaritmik sebagai model disarankan untuk digunakan hanya jika ditemui kesulitan untuk menyesuaikan model sederhana, dimana volume tidak ditransformasikan karena fungsi logaritmik akan menghasilkan bias dan ketelitian pendugaan dari sejumlah pohon tidak dapat diketahui (Susanty \& Siran, 2005).
Pada tahap validasi model adalah untuk mengevaluasi model atau persamaan regresi yang terbentuk sebagai penduga volume dengan harapan memberikan simpangan baku sisaan seminimal mungkin (Loestch et al., 1973). Pada tahap ini masing-masing model atau persamaan regresi dilakukan perhitungan simpangan agregatif, simpangan rataan dan RMSE. Berikut hasil perhitungan validasi model untuk jenis $S$. parvifolia, S. dasyphylla, $S$. leprosula dan gabungan (3 jenis) disajikan pada Tabel 8.

\section{Validasi model}

Tabel 8. Hasil validasi model volume berdasarkan nilai simpangan agregatif (sa), simpangan rataan (sr) dan Root Mean Square Error (RMSE)

Table 8. Result of validation on volume model based on agregative deviation (sa), average deviation (sr) and Root Mean Square Error (RMSE)

\begin{tabular}{|c|c|c|c|}
\hline Persamaan regresi & sa & $\operatorname{sr}(\%)$ & RMSE \\
\hline \multicolumn{4}{|l|}{ S. parvifolia } \\
\hline $\mathrm{V}=-0,3381+0,001355 \cdot \mathrm{d}^{2}$ & 6,42 & 58,38 & 37,69 \\
\hline $\mathrm{V}=0,00007979 . \mathrm{d}^{2,67646}$ & 1,07 & 9,76 & 16,08 \\
\hline $\mathrm{V}=0,001 \mathrm{~d}^{2}-0,007 \mathrm{~d}-0,156$ & 2,53 & 23,01 & 54,77 \\
\hline \multicolumn{4}{|l|}{ S. dasyphylla } \\
\hline$V=-0,6369+0,001517 \cdot d^{2}$ & 1,06 & 9,62 & 115,80 \\
\hline $\mathrm{V}=0,00005024 \cdot \mathrm{d}^{2,80036}$ & 0,68 & 6,19 & 16,42 \\
\hline $\mathrm{V}=0,001 d^{2}-0,045 d+0,389$ & 11,68 & 106,15 & 105,02 \\
\hline \multicolumn{4}{|l|}{ S. leprosula } \\
\hline $\mathrm{V}=-0,50766+0,001423 \cdot \mathrm{d}^{2}$ & 1,32 & 12,03 & 208,66 \\
\hline $\mathrm{V}=0,000082137 \cdot \mathrm{d}^{2,67286}$ & 0,03 & 0,29 & 15,45 \\
\hline $\mathrm{V}=0,001 \mathrm{~d}^{2}-0,025 \mathrm{~d}-0,026$ & 36,18 & 328,93 & 161,53 \\
\hline \multicolumn{4}{|l|}{ Gabungan (3 jenis) } \\
\hline$V=-0,43029+0,001392 \cdot d^{2}$ & 0,88 & 2,94 & 104,22 \\
\hline $\mathrm{V}=0,000070611 \cdot \mathrm{d}^{2,71000}$ & 1,70 & 5,66 & 15,99 \\
\hline $\mathrm{V}=0,001 \mathrm{~d}^{2}-0,006 \mathrm{~d}-0,278$ & 10,73 & 35,77 & 111,28 \\
\hline
\end{tabular}

Keterangan: $\mathrm{V}=$ volume bebas cabang $\left(\mathrm{m}^{3}\right) ; \mathrm{d}=$ diameter setinggi dada $(\mathrm{cm})$.

Penilaian model terbaik pada tahap validasi model disusun berdasarkan nilai-nilai simpangan agregatif (sa), simpangan rataan (sr) dan Root Mean Square Error (RMSE), dengan rekapitulasi pemeringkatan pada tahap validasi disajikan pada Tabel 9 berikut :

Tabel 9. Penentuan peringkat pada tahap validasi model

Table 9. Scoring on model validation stage

\begin{tabular}{llcccc}
\hline \multicolumn{1}{c}{ Persamaan } & sa & sr (\%) & RMSE & $\sum$ & Peringkat \\
\hline S. parvifolia & & & & & \\
\hline Kopezky-Gehrhardt & 3 & 3 & 3 & 9 & 3 \\
\hline Berkhout & 1 & 1 & 1 & 3 & 1 \\
\hline Hohenadl-Krenn & 2 & 2 & 2 & 6 & 2 \\
\hline S. dasyphylla & & & & & \\
\hline Kopezky-Gehrhardt & 2 & 2 & 3 & 7 & 2 \\
\hline Berkhout & 1 & 1 & 1 & 3 & 1 \\
\hline Hohenadl-Krenn & 3 & 3 & 2 & 8 & 3 \\
\hline S. leprosula & & & & & \\
\hline Kopezky-Gehrhardt & 2 & 2 & 3 & 7 & 2 \\
\hline
\end{tabular}




\begin{tabular}{|c|c|c|c|c|c|}
\hline Berkhout & 1 & 1 & 1 & 3 & 1 \\
\hline Hohenadl-Krenn & 3 & 3 & 2 & 8 & 3 \\
\hline \multicolumn{6}{|l|}{ Gabungan (3 jenis) } \\
\hline Kopezky-Gehrhardt & 1 & 1 & 2 & 4 & 1 \\
\hline Berkhout & 2 & 2 & 1 & 5 & 2 \\
\hline Hohenadl-Krenn & 3 & 3 & 3 & 9 & 3 \\
\hline
\end{tabular}

Berdasarkan hasil pemeringkatan pada tahap validasi model menunjukkan bahwa model Berkhout diterima sebagai model yang terbaik pada tingkat jenis untuk ketiga jenis $S$. parvifolia, $S$. dasyphylla dan $S$. leprosula. Sedangkan pada tingkat gabungan, model terbaik adalah model Kopezky-Gehrhardt. Model Berkhout banyak diterima dalam beberapa penyusunan model pendugaan volume pohon khususnya jenis Dipterocarpaceae di wilayah Kalimantan
(Susanty dan Siran, 2005; Lestarian, 2009; Fatah, 2009; Riady, 2011; Permadi, 2014), serta untuk jenis Dipterocarpaceae di luar Kalimantan (Ardelina, 2011; Andhika, 2012; Ulfah, 2012).

Ditinjau dari kedua tahapan pembentukan model yaitu penyusunan dan validasi model, maka penentuan model terbaik dapat dilihat dari hasil pemeringkatan pada Tabel 10 berikut :

Tabel 10. Penentuan peringkat tahapan penyusunan dan validasi model

Table 10. Scoring determination on model development and validation stage

\begin{tabular}{|c|c|c|c|c|c|}
\hline \multirow{2}{*}{ Model } & \multirow{2}{*}{ Persamaan regresi } & \multicolumn{2}{|c|}{ Tahap } & \multirow{2}{*}{$\sum$} & \multirow{2}{*}{ Peringkat } \\
\hline & & Penyusunan & Validasi & & \\
\hline \multicolumn{6}{|l|}{ S. parvifolia } \\
\hline Kopezky-Gehrhardt & $\mathrm{V}=-0,3381+0,001355 \cdot \mathrm{d}^{2}$ & 4 & 9 & 13 & 2 \\
\hline Berkhout & $\mathrm{V}=0,00007979 . \mathrm{d}^{2,67646}$ & 7 & 3 & 10 & 1 \\
\hline Hohenadl-Krenn & $\mathrm{V}=0,001 d^{2}-0,007 d-0,156$ & 7 & 6 & 13 & 2 \\
\hline \multicolumn{6}{|l|}{ S. dasyphylla } \\
\hline Kopezky-Gehrhardt & $\mathrm{V}=-0,6369+0,001517 \cdot \mathrm{d}^{2}$ & 6 & 7 & 13 & 2 \\
\hline Berkhout & $\mathrm{V}=0,00005024 . \mathrm{d}^{2,80036}$ & 7 & 3 & 10 & 1 \\
\hline Hohenadl-Krenn & $\mathrm{V}=0,001 d^{2}-0,045 d+0,389$ & 5 & 8 & 13 & 2 \\
\hline \multicolumn{6}{|l|}{ S. leprosula } \\
\hline Kopezky-Gehrhardt & $V=-0,50766+0,001423 \cdot d^{2}$ & 4 & 7 & 11 & 2 \\
\hline Berkhout & $\mathrm{V}=0,000082137 . \mathrm{d}^{2,67286}$ & 6 & 3 & 9 & 1 \\
\hline Hohenadl-Krenn & $\mathrm{V}=0,001 \mathrm{~d}^{2}-0,025 \mathrm{~d}-0,026$ & 6 & 8 & 14 & 3 \\
\hline \multicolumn{6}{|l|}{ Gabungan (3 jenis) } \\
\hline Kopezky-Gehrhardt & $V=-0,43029+0,001392 \cdot d^{2}$ & 5 & 4 & 9 & 1 \\
\hline Berkhout & $\mathrm{V}=0,000070611 . \mathrm{d}^{2,71000}$ & 7 & 5 & 12 & 2 \\
\hline Hohenadl-Krenn & $\mathrm{V}=0,001 \mathrm{~d}^{2}-0,006 \mathrm{~d}-0,278$ & 6 & 9 & 15 & 3 \\
\hline $\begin{array}{lll}\text { Keterangan } & : \mathrm{V}\end{array}$ & $=$ volume bebas cabang & $\left(\mathrm{m}^{3}\right)$ & diameter & & dada \\
\hline
\end{tabular}

Berdasarkan hasil pemeringkatan gabungan pada kedua tahapan penyusunan dan validasi model menunjukkan bahwa model Berkhout diterima sebagai model yang terbaik pada tingkat jenis untuk ketiga jenis $S$. parvifolia, $S$. dasyphylla dan $S$. leprosula. Sedangkan pada tingkat gabungan, model terbaik adalah model Kopezky-Gehrhardt. Sebagian hasil-hasil penelitian sebelumnya menunjukkan adanya variasi penerimaan model pendugaan volume untuk kelompok jenis Dipterocarpaceae, dimana model pendugaan volume Berkhout banyak diterima dalam penelitian penyusunan model volume (Lestarian, 2009; Ardelina, 2011; Riady, 2011; Permadi, 2014).

Heigliman and Bratkovich (2009) dari Ohio Department of Natural Resources Division of Forestry Service, dalam pengukuran pohon berdiri, ditentukan tinggi merchantable (ukuran tinggi pohon yang dapat dijual) untuk menentukan volume. Penghitungan estimasi volume pohon diperlukan untuk menghitung jumlah yang 
dapat dijual seperti dalam bentuk kayu gergajian, suatu estimasi volume diperlukan untuk menentukan berapa ukuran dan berapa bayak pohon yang harus ditebang.

Akan terjadi financial loss yang sangat besar jika tidak memperhatikan aspek kualitas kayu dalam pohon berdiri sebelum penebangan (Kern, 2009).

\section{KESIMPULAN}

Pemilihan model atau persamaan regresi terbaik dalam penyusunan model pendugaan volume pohon untuk penyusunan tabel volume, merupakan gabungan penilaian pemilihan model pada tahap penyusunan dan validasi model. Pemilihan model terbaik pada tahap penyusunan model berdasarkan nilainilai koefisien determinasi $\left(\mathrm{R}^{2}\right)$, standar error (SE) dan $F_{\text {hitung. Sedangkan penilaian model }}$ terbaik pada tahap validasi model berdasarkan nilai-nilai simpangan agregatif ( $\mathrm{sa}$ ), simpangan rataan (sr) dan Root Mean Square Error (RMSE).

Model Berkhout diterima sebagai model yang terbaik untuk jenis $S$. parvifolia, $S$. dasyphylla dan $S$. leprosula pada wilayah hutan alam IUPHHK PT. Intracawood Manufacturing, Tarakan. Berturut-turut model pendugaan volume terbaik sebagai penyusun tariff (tabel volume lokal) untuk masingmasing jenis adalah :

$$
\begin{array}{ll}
\text { S. parvifolia } & \mathrm{V}=0,00007979 . \mathrm{D}^{2,67646} \\
\text { S. dasyphylla } & \mathrm{V}=0,00005024 . \mathrm{D}^{2,80036} \\
\text { S. leprosula } & \mathrm{V}=0,000082137 . \mathrm{D}^{2,67286}
\end{array}
$$

Sedangkan model volume gabungan (3 jenis) mempunyai model Kopezky-Gehrhardt yaitu $\mathrm{V}=-0,43029+0,001392 . \mathrm{D}^{2}$.

Teknik pengukuran dan penyusunan pendugaan volume pohon pada pohon berdiri akan mempunyai keuntungan untuk aplikasinya pada hutan-hutan yang tidak ada kegiatan penebangan di dalamnya. Tetapi jumlah dan representative (tingkat keterwakilan) pohon sampel untuk jenis atau kelompok jenis yang dibangun perlu menjadi pertimbangan.

Kebutuhan akan tersedianya alat ukur Tele Relaskop menjadi penting untuk meningkatkan akurasi pengukuran pohon sampel. Di samping itu perlu kajian tingkat ketelitian atau bias yang diperoleh dari teknik pengukuran pada tegakan pohon berdiri dengan teknik pengukuran pada pohon rebah atau melalui penebangan untuk penilaian efisiensi.

\section{DAFTAR PUSTAKA}

Andhika, H. (2012). Persamaan Penduga Volume Pohon Meranti merah (Shorea stenoptera Burck)di KHDTK Haurbentes, Kabupaten Bogor Propinsi Jawa Barat. Skripsi Departemen Manajemen Hutan Fakultas Kehutanan, Institut Pertanian Bogor. Bogor.

Ardelina, A. (2011). Penyusunan Tabel Volume Lokal Kelompok Jenis Dipterocarpaceae (Anisoptera spp dan Vatica spp.) di Areal Kerja IUPHHKHA PT. Mamberano Alas Mandiri, Propinsi Papua. Skripsi Departemen Manajemen Hutan Fakultas Kehutanan, Institut Pertanian Bogor. Bogor.

Bustomi, S., Harbagung, Wahyono, D dan Parthama, IBP. (1998). Petunjuk Teknis Tata Cara Penyusunan Tabel Volume Pohon. Badan Penelitian dan Pengembangan Kehutanan. Pusat Penelitian dan Pengembangan Hutan dan Konservasi Alam. Info Hutan, Bogor.

Fatah, N. (2009). Penyusunan Tabel Volume Lokal Tegakan Hutan Alam pada Areal IUPHHK PT. Trisetia Intiga di Kabupaten Lamandau, Kalimantan Tengah. Skripsi Departemen Manajemen Hutan Fakultas Kehutanan, Institut Pertanian Bogor. Bogor.

Heigliman, R.B. dan Bratkovich, S.M. (2002). Measuring Standing Trees-Determining Diameter, Merchantable Height, and Volume. Ohio State University Fact Sheet - School of Natural Resources

Husch, B. (1963). Forest Mensuration and Statistics. The Ronald Press Company. New York.

Husch, B., T.W. Beers and J.A. Kershaw, JR. (2003). Forest Mensuration. Fourth Edition. John Wiley \& Sons, Inc. Hoboken, New Jersey.

Kern. (2009). Tree Inventory Technician. Tree Foundation Kern.

Lestarian, R. (2009). Penyusunan Tabel Volume Pohon Kelompok Jenis Dipterocarpaceae dan Kelompok Jenis Kayu Rimba Campuran dalam rangka Pelaksanaan IHMB di PT. Ratah Timber Kalimantan Timur. Skripsi Departemen Manajemen Hutan Fakultas Kehutanan, Institut Pertanian Bogor. Bogor.

Loetsch, F., E. Zohrer and K. E. Heller. (1973). Forestry Inventory. Volume II. BI. V. Verlagsgesselshalft MBH. Munchen.

Oderwald, R.G. dan Johnson, J.E. (2004). Measuring Standing Trees and Logs. Virginia Polytechnic 
Institute and State University : 420-560. Virginia

Pambudhi, F. (1995). Pembentukan Tabel Volume untuk Jenis-jenis Meranti Perdagangan di Damai Kaltim Indonesia, Universitas Mulawarman, Samarinda.

Permadi, I. (2014). Tabel Volume Lokal Meranti merah (Shorea leprosula Miq) dan Meranti kuning (Shorea multiflora Miq)di areal IUPHHK-HA Propinsi Kalimantan Tengah. Skripsi Departemen Manajemen Hutan Fakultas Kehutanan, Institut Pertanian Bogor. Bogor.

Philip M.S. (1998). Measuring Trees and Forests. CABI Publishing. University Press, Cambridge.

Prodan M. (1968). Forest Biometrics. First Edition. Gardiner SH, penerjemah. Oxford (GB): Pergamon Press. Terjemahan dari: Forstliche Biometrie.

Riady, A. (2011). Penyusunan dan Validasi Persamaan Tabel Volume Lokal Pohon Meranti (Shorea spp) di Areal PT. Intracawood Manufacturing, Kalimantan Timur. Skripsi Departemen Manajemen Hutan Fakultas Kehutanan, Institut Pertanian Bogor. Bogor.

Siswanto, B. E., dan R. Imanuddin. (2008). Model Pendugaan Isi Pohon Agathis loranthifolia Salisb di Kesatuan Pemangkuan Hutan Kedu
Selatan, Jawa Tengah. Jurnal Penelitian Hutan dan Konservasi Alam. 5(5) : 485-496.

Steel RGD, Torrie JH. (1995). Prinsip dan Prosedur Statistika. Suatu Pendekatan Biometrik. Edisi ke-2. Sumantri B, penerjemah. Jakarta (ID): Penerbit PT Gramedia Pustaka Utama. Terjemahan dari: Principles and Procedures of Statistics.

Suharlan, A dan Sudiono, Y. (1977). Ilmu Ukur Kayu. Bagian Nilai Hutan. LPH. Bogor.

Susanty, F. H. dan S. A. Siran. (2005). Status Riset Penyusunan Tabel Volume Pohon. Balai Penelitian dan Pengembangan Kehutanan Kalimantan. Samarinda.

Ulfah, M. (2012). Persamaan Penduga Volume Pohon Meranti (Shorea mecistopteryx Ridl) di KHDTK Haurbentes, Kabupaten Bogor Propinsi Jawa Barat. Skripsi Departemen Manajemen Hutan Fakultas Kehutanan, Institut Pertanian Bogor. Bogor.

Utomo, P. M. dan Rachman, E. 2002. Pendugaan Volume Pohon Jenis Ketapang (Terminalia bellorica) di Kawasan Hutan Teluk Kamrau, Kaimana. MATOA (12) Informasi Teknis Balai Penelitian Kehutanan Manokwari. Manokwari.

Walpole, 1993 Pengantar Statistik. Edisi 3 (Terjemahan). Gramedia Jakarta. 
JURNAL Penelitian Ekosistem Dipterokarpa Vol. 2 No. 1, Juli 2016 Hal. 29-40

P-ISSN: 2460-5875 | E-ISSN: 2460-5883 